\title{
Bahçede Uygulanan Okul Öncesi Eğitimin Çocukların Problem Davranışlarına ve Sosyal Becerilerine Etkisi ${ }^{1}$
}

\author{
Şenay ŞİRIN KAYA² ve Arzu ÖZYÜREK ${ }^{3}$
}

$\ddot{O} z$

$\mathrm{Bu}$ araşıtımada, bahçede uygulanan okul öncesi eğitim etkinliklerinin çocukların problem davranışlarına ve sosyal becerilerine etkisinin incelenmesi amaçlanmıştır. Araştırmanın çalışma grubunu Ankara İl merkezinde Aile Sosyal Politikalar Bakanlığına bağh iki anaokuluna devam eden 19 kız, 21 erkek olmak üzere toplam 40 çocuk oluşturmuştur. Bir anaokulundan $10 \mathrm{k} ı$ ve 10 erkek 20 çocuk deney grubuna, diğer anaokulundan ise 9 kız, 11 erkek 20 çocuk kontrol grubuna atanmışıtır. Araştırmada ön test-son test kontrol gruplu yarı deneysel desen kullanılmıştır. Deney grubu üç ay süreyle tüm gün etkinliklerini bahçede gerçekleştirirken kontrol grubu okul içinde eğitimlerine devam etmiştir. Verilerin toplanmasında, Okul Öncesi ve Anasınıfı Davranış Ölçeği ön test ve son test olarak kullanılmıştır. Verilerin değerlendirilmesinde Mann Whitney U Testi, Wilcoxon İşaretli Sıralar Testi, Spearman Brown korelasyon katsayısından yararlanılmıştır. Sonuç olarak; deneysel uygulama öncesinden sonrasına deney grubundaki çocukların problem davranışlarında azalma, sosyal becerilerinde ise anlamlı düzeyde artış gözlemlenmiştir. Genel olarak çocukların sosyal becerileri ile problem davranışları arasında anlamlı bir ilişki olduğu, sosyal beceriler arttıkça problem davranışların azaldığı belirlenmiştir.

Anabtar Kelimeler: Bahçe etkinlikleri, Açı alan etkinlikleri, Okul öncesi dönem, Sosyal beceri, Problem davranış

The Effect of Preschool Education Applied in The Garden on Children's Problem Behaviors and Social Skills

\begin{abstract}
The study aimed to examine the effects of preschool education activities applied in the garden on children's problem behaviors and social skills. The group under study consisted of 19 girls and 21 boys, 40 children in total, attending 2 kindergartens and 2 preschools affiliated to the Ministry of Family and Social Policies in Ankara city center. 20 children, 10 girls, and 10 boys, from one kindergarten and one preschool, were assigned to the experimental group whilst 9 girls and 11 boys, 20 children in total, attending the other kindergarten and preschool were assigned to the control group. The experimental design with a pre-test/post-test control group was used in this study. While the experimental group carried out all-day activities in the garden for three months, the control group continued their education inside the school. Preschool and Kindergarten Behavior Scale developed by Merrell (1994) was used as a pre-test and post-test. Mann Whitney U test, Wilcoxon Signed Ranks Test, Spearman-Brown Correlation Coefficient was used in the evaluation of the data. As a result; A decrease in the problem behaviors of the children assigned to the experimental group, and a meaningful increase in their social skills were observed after the experiment, compared to before. In general, it was determined that there was a significant relationship between children's social skills and problem behaviors, and as social skills increased problem behaviors decreased.
\end{abstract}

Key Words: Garden activities, Preschool term, Social skill, Problem behavior

\section{Atıf İçin / Please Cite As:}

Şirin Kaya, Ş. ve Özyürek, A. (2022). Bahçede uygulanan okul öncesi eğitimin çocukların problem davranışlarına ve sosyal becerilerine etkisi. Manas Sosyal Araștırmalar Dergisi, 11(1), 128-142.

Geliş Tarihi / Received Date: 14.03.2021

Kabul Tarihi / Accepted Date: 28.06.2021

\footnotetext{
${ }^{1}$ Bu çalışma, Prof. Dr. Arzu ÖZYÜREK danışmanlı̆̆ında Şenay ŞİRINN KAYA tarafından hazırlanan yüksek lisans tezinden üretilmiştir.

2 Öğr. Gör.- İstanbul Şişli Meslek Yüksekokulu, sirin.kaya@sisli.edu.tr

(iD) ORCID: 0000-0001-9294-3855

${ }_{3}^{3}$ Prof. Dr. - Karabük Üniversitesi Sağlık Bilimleri Fakültesi, karabuk_arzu@yahoo.com 


\section{Giriş}

Ülkelerin gelişmesinde, bireylerin eğitimi çok önemli bir yer tutmaktadır. Eğitim ise ailede başlayıp sosyal yaşam, okul ve çevrenin etkisiyle devam etmektedir. Bu açıdan bakıldığında okul öncesi dönemde eğitimin, bireyin aileden sonraki en önemli eğitsel çevresini oluşturduğu söylenebilir. Okul öncesi eğitim kurumlarında, alternatif eğitim yaklaşımları doğrultusunda farklı eğitim programları gerçekleştirilmektedir. Geleneksel yaklaşımlarda çocuklardan pasif bir şekilde beklemesi, söyleneni yapması, ezberlemesi istenirken modern yaklaşımlarda çocuğun yaparak-yaşayarak öğrendiği, etkin olarak sürece katıldığ bir eğitim ortamının yaratıldığı görülmektedir (Temel ve Dere, 1999, s. 4; Açıkgöz, 2002, s. 10). Bu yaklaşımlarda çocukların çevreyle aktif şekilde etkileşimi sağlanarak ilgilerini ve yaratıcılıklarını desteklemek, iletişim becerilerini güçlendirmek amaçlanmaktadır (Dinçer ve Anlıak, 2005, s. 3). Bunun için ise eğitim ortamının düzenlenmesi önem arz etmektedir.

Okul öncesi eğitim ortamları bahçe, ormanlık alanlar, piknik alanları vb. kapsayan dış mekân ve sınıf ortamından oluşan iç mekân olarak ele alınmaktadır (Ford, 1986, s. 20). Okullar, eğitimin sınıf içerisinde gerçekleşeceği düşüncesiyle daha çok dış mekânlar göz ardı edilerek planlanmaktadır. Oysa dış mekânlarda yapılan etkinlikler, çocuklarda hedeflenen gelişimsel kazanımlara ulaşılmasını kolaylaştıracaktır. Günümüzde, şehirleşmeyle birlikte çocukların hem güvenle vakit geçirip hem de gelişimlerinin destekleneceği açık oyun alanları diş mekânlardan iç mekânlara kaymış durumdadır. Özellikle büyük şehirlerde çocuklar açık alanların olmaması nedeniyle doğadan uzak büyümekte ve zamanlarının çoğunu iç mekânlarda geçirmektedirler (Başal, 2005, s. 400). Oyun alanlarında yaşanan bu durumun çocukların gelişimini çeşitli yönlerden olumsuz etkilediği söylenebilir. Bu durum geleneksel grup oyunlarının ortadan kalkmasına, çocukların sosyal ortamlardan uzaklaşarak televizyon izleme ve bilgisayar, cep telefonu, tablet gibi dijital ortamlara yönelmesine neden olmaktadır (Wake, Hesketh ve Waters, 2003, s. 188). Televizyon, bilgisayar, tablet ve telefon gibi kitle iletişim araçlarının sık kullanımı, çocukların bilişsel olarak zayıflamasına neden olmakla birlikte yaratıcı ve eğlenceli oyun aktivitelerini de engellemektedir (Strasburger ve Donnerstein, 1999, s. 50). Oysa açı alan olarak adlandırlan doğa, çocuğu hayata hazırlayan, oyun oynadıkça becerilerini arttıran ve yeteneklerini geliştiren en etkin ve doğal yoldur. Bu nedenle, okul öncesi eğitim kurumlarının açı alanlarını düzenlemeleri gerekmektedir.

Okullarda öğretmenlerin açık alan etkinliklerine çocukların istek ve ihtiyaçları doğrultusunda yer vermesi ve çocuklara doğada firsatlar sunması hem çocukların gelişimlerini sağlıkla tamamlamasına hem de doğayı seven ve koruyan bireyler olarak yetişmelerine katkı sağlayacaktır. Fakat ülkemizde açık alanı hiç bulunmayan anaokulları mevcuttur. Açık alanı/bahçesi olan okulların ise çoğu ya büyüklük açısından kullanıma uygun değildir ya da plastik park araç-gereçleriyle donatılmış olup hedeflenen gelişimi desteklememektedir (Çelik, 2012, s. 80). Çocuğun fiziksel gelişimine, sosyalleşmesine, yaşamı anlamasına ve kişiliğini oluşturabilmesine katkı sağlayan oyunun, özellikle açık ve yapılandırılmamış alanlarda oynanması ideal olandır. Değişen yaşam koşulları çocukları doğadan kopartmaktadır ve bu durum çocukların zihinsel gelişimi başta olmak üzere tüm gelişim alanlarını olumsuz yönde etkilemektedir (Sivri, 1993, s. 50). Ayrıca aktif olarak oynanan oyunların sağladığı hızlı ve kalıcı öğrenme de yok olmakta, ezber bilgi artmakta, pasif bir yaşam sürdüren çocukların gelişimleri olumsuz etkilenmektedir. Açık alanda vakit geçirmenin çocuklara sağladığı yararları incelemek için yapılan araştırmalara göre açık alanda vakit geçirmenin çocukların fiziksel gelişimlerine destek sağladığı, dikkat sürelerini arttırdığı, üretken ve işbirliğine yatkın bireyler olmasına katk1 sağladığı belirtilmektedir. Bağışıklık sistemini güçlendirdiği, D vitaminin etkisiyle üretkenliği ve öğrenmeyi arttırdığı da vurgulanmaktadır (Akk1lıç Kansu, 2009, s. 85).

Sınıf içi ortamlar, en az üç-dört çocuğun birlikte vakit geçirebileceği çok amaçlı kullanıma yönelik alanlardır. Sınıf dışı eğitim ortamları ise eğitimin duvarlara ihtiyaç duymadan yapılabileceğini vurgulayan, deneysel olduğu için çocukların doğrudan katılım gösterdiği, çocukların eğitimde geçen olayları duyularını kullanarak uygulama firsatı yakaladı̆̆ı, sınıftan farklı bir mekân olduğu için çocuklar tarafından ilginç ve heyecanlı bulunan ortamlardır (Priest, 1986, s. 14; Tsai, 2006, s. 20). Piaget, bir çocuğun sürekli yeni şeyler duymak ve görmek isteyeceğini ve yeni şeyler gördüğü ortamlardan zihinsel gelişiminin etkilendiğini vurgulamaktadır. John Dewey, Maria Montessori, LorisMalaguzzi ve sonraki eğitimciler en iyi öğrenmenin somut deneyimler ve iyi donatılmış eğitim ortamlarıyla gerçekleştiğini belirtmişlerdir. Eğitim ortamları ihtiyaç duyulan personel, iç ve diş fiziksel mekân, donanım ve araç gereçleri içeren; fiziksel özellikler olarak ulaşıma yakın, çevresi açık ve gürültüden uzak, bahçeyle bütünleşmiş dinamik bir yapıda olmalıdır. Bahçede çimenli/çakıllı alanlar, bisiklet alanlanı, kum havuzu, ağaçlar, toprak tepecikler, küçük evler, bitki bahçeleri, 
hayvan besleme alanları vb. yerler oluşturulmalıdır (Akt: Poyraz ve Dere, 2003, s. 10; MEB Mevzuatı 2018).Okullarda öğretmenler, genellikle yağmur ve çamurun ya da çok sıcağın olmadığı bahar aylarında çocukları bahçeye çıkararak ihtiyaçlarını karşılamayı tercih etmektedirler. Ama açı alanda geçirilen bu süre, çocuğun gelişimini sağlıklı tamamlamasında yeterli olmamaktadır (Çelik, 2012, s. 78). Oysa açık alanlar çocukların büyümelerine ve zihinsel, sosyal, duygusal gibi tüm alanlardaki gelişmelerine de olanak sağlar.

Açık havada gerçekleştirilen etkinlikler çocuklarda konsantrasyon, otonomi ve öz disiplin becerilerinin desteklenmesini sağlar (White, 2004, s. 130). Çocukların alıcı ve ifade edici dil becerileriyle birlikte bir durum karşısında çıkarım yapma, olayları ve süreci planlama, süreç ile ilgili karar verme, kendisinin ve çevresinin farkına varma çevresinde gerçekleşen olaylarla ilgili gözlem yapma gibi zihinsel becerileri desteklenir. El-göz koordinasyonu, denge gibi motor becerileri doğayla etkileşim sonucunda daha çok artış gösterir. Asosyal davranışların azaldı̆̆ı, işbirliği, dayanışma, uzlaşma ve çatışma çözme becerilerinin arttı̆̆1 gözlenir (Burdette ve Whitaker, 2005, s. 657). Çocuklar, sosyal duygusal yönden açık alan etkinlikleri sayesinde toplum içinde istenilen ve beklenen davranışı gerçekleştirmeyi, aldığı sorumlulukları yerine getirmeyi, sıra bekleme saygılı olma gibi toplum kurallarına uymayı, paylaşmayı öğrenirler. Bu aşamada, çocuklarda görülme olasılığı yüksek problem davranışların açık alanda geçirilen zamanla ilişkilendirilmesi mümkündür. Okul öncesi eğitim, çocukların gelişim alanlarını desteklerken aynı zamanda çocukların toplum içinde davranış problemlerini önleyerek olumlu davranışlar kazanmaları ve öz düzenlemelerini sağlayan bireyler olmaları için zihinsel, duygusal ve sosyal yönden desteklendikleri bir ortamdır. Bu ortamda, çocuğun bir davranışı yapmama yetisine sahip olduğu halde çocuktan davranışı yapmaması istendiğinde, çocuk bu davranışı tekrarlamaya devam ediyor ise, bu durum davranış problemi olarak kabul edilmektedir (Birkan, 2002, s. 18). Alan yazında okul öncesi dönem çocuklarda yalan söyleme, yemek seçme/yemeye isteksizlik, anne-babadan ayrılma korkusu, kıskançlık, inatçllık, saldırganlık, konuşma bozukluğu, alt 1slatma/dışkı kaçırma, tırnak yeme, dikkat eksikliği, karanlıktan korkma, çalma, parmak emme ve tik gibi problem davranışların görüldüğüne dair pek çok araştırma bulgusu yer almaktadır (Akman, Baydemir, Akyol, Arslan ve Kükütçü, 2011, s. 1715; Alisinanoğlu ve Kesicioğlu, 2010, s. 30; Dearing, 2014, s. 37; Eratay, 2011, s. 2347; Derman ve Başal, 2013, s. 115; Özbey, 2010, s. 9; Turney ve McLanahan, 2015, s. 131; Zachrisson ve Dearing, 2015, s. 425). Çocukların problem davranışlar olarak adlandırılan istenmeyen davranışlar göstermeleri yalnızca kendileri için değil tüm öğrenciler açısından olumsuz durumlar oluşturmaktadır.

Problem davranışların sıklığını hem de problem olarak görülme durumunu etkileyen pek çok faktörden söz edilebilir. Yavuzer (2001, s. 20) davranış problemlerinin ortaya çıkmasını genetik özellikler, fiziksel nedenler, temel gereksinimlerinin karşılanmaması, çevresel faktörler, anne-baba tutumları olarak ifade etmiştir. Davranış problemleri görülmesinde anne-baba-çocuk iletişimi ve çocuğun doğayla etkileşiminin de etkisi çok yüksektir (Kandır, 2000, s. 42). Çocuğun birçok olumlu davranışı kazanmasında aynı zamanda da birçok olumsuz davranışının da engellenmesinde, çevresel faktörlerin büyük önem taşıdığı görülmektedir. Örneğin; kalabalık ve fazla eşyanın bulunduğu bir sınıf ortamında aktivite yapmak isteyen çocukların birbirini itmek gibi istenmeyen davranışlar göstermesi söz konusu olabilir. Bulunulan ortam davranış problemlerine neden olurken kişiler arası ilişkileri de olumsuz yönde etkileyebilmektedir. $\mathrm{Bu}$ aşamada, sosyal becerilerin gelişimi de akla gelmektedir. Çocukların aile hayatından sonra ilk deneyimlerini yaşadıkları okul öncesi eğitim ortamlarının bilinçli düzenlenmesi, çocukların toplumsal düzeni anlamaları ve daha iyi bir geleceğe sahip olmaları için gereklidir (Gezgin, 2009; Yumuş, 2013).

Sosyal beceriler; çocuğun akranlarıla etkileşimi başlatma ve sürdürme, sorumluluklar alma, grup çalışması yapabilme, duyguları tanıma, saldırganlık ve stres gibi olumsuz duygularla baş etmeye yönelik beceriler, planlama ve problem çözme becerileri, kendini kontrol edebilme ve atılganlık becerileri olarak tanımlanabilir (Özyürek ve Ceylan, 2014, s. 99). Toplumun gelişmesinde önemli bir yeri olan sosyal becerilerin kazanımı çocukluk döneminden itibaren, sistematik bir şekilde aile-okul işbirliğiyle gerçekleștirilmelidir. Çocuk bu becerileri gözlemleyip taklit ederek kazanır. Bandura'nın sosyal öğrenme teorisine göre insanların gerçekleştirdiği davranışlar çevresel faktörlerin karşlıklı iletişimiyle açıklanabilir. Bandura, teorisinde gözlem yoluyla öğrenme üzerinde durmuş ve gözlem yoluyla öğrenmeyi çevresine dikkat etme, öğrenilenleri hafızada saklama, güdülenerek davranışı meydana getirme şeklinde açıklamıştır (Akt: Senemoğlu, 2001, s. 10). Okul öncesi yıllarda sosyalleşme, öncelikle ev ortamında başlarken çocuğun okula başlamasıyla birlikte akran etkileşimleriyle devam eder. Okul öncesi yillarda sosyal becerilerin kazanılmış olması, okul dönemindeki akademik başarının ön koşuludur. Aksi halde davranış problemleri görülebilir. Bulunduğu grup tarafından kabul görmek için akademik becerileri de kapsayan sosyal becerilerin okul öncesi ylllarda sağlıklı bir şekilde kazanılması gerekir (Ceylan ve Yiğitalp, 2018, s. 119). 
Sosyal açıdan yeterli olan çocuklar akranları tarafından kabul görüp yetişkinlerle olumlu ilişkiler kurarken aksi durumda problem davranışlar sergileyen bireyler olarak nitelendirilebilirler.

Çocuklar sağlıklı büyüme ve gelişme, fiziksel ve psikolojik yönden sağlıklı olmak için düzenli olarak hareket etmeye, açık hava ve güneşe gereksinim duyarlar. Bu gereksinimlerinin karşılanmaması, çocukların gelişme sürecinde çeşitli davranış problemleri göstermelerine neden olur (Carr ve Durand, 1985). Problem davranışlar, çocuğun toplumda aktif olarak rol almasını engelleyen hem kendinin hem de akranının güvenliğini tehlikeye atan, toplum içinde kabul edilmeyen davranışlar olarak adlandırılmaktadır (Carr ve Durand, 1985, s. 219). Ayrıca problem davranışlar, akranlar ile sosyalleşmeyi de olumsuz olarak etkilemekte ve bireyin hem kendisine hem çevresine istenmeyen davranışlarda bulunmasına neden olabilmektedir. Erken çocukluk dönemindeki çocukların davranış problemlerinin kontrol altında tutulması için de açık hava etkinliklerinden faydalanılması gerekmektedir (Louv, 2016). Açık havada oynanan oyunlar çocukları toplum içerisinde empati, hoşgörü, anlayış ve işbirliğine de teşvik etmektedir. İnce ve kaba motor beceriler için gereken kasların çalışmasını desteklemekte, olumsuzluklarla baş etmeyi öğretmekte, doğayla ilişkilerini geliştirmektedir. Çocukların içe kapanık, çekingen veya alıngan olmasına engellemektedir. Açı havada oyun oynayan ve vakit geçiren çocuklar D vitamininden daha fazla yararlandıkları için bağışıklık sistemleri güçlenmektedir (Uyanık Balat, Şimşek ve Akman, 2008, s. 263). Oyun ve özellikle açık havada oynanan oyunlarının çocukların temel gereksinimlerinden biri olduğunun farkına varmak ve çocuklara açı havada oyun oynama firsatı vermek gerekmektedir. Açık alanda geçirilen zamana bağlı olarak çocukların gelişimlerinde, davranışlarında ve öğrenmelerinde anlamlı farklılıklar ortaya çıkabilir.

Alan yazında, çocuklarla gerçekleştirilen eğitim programlarının problem davranışların ve sosyal beceri gelişimi üzerinde etkili olduğunu göstermektedir. Avcıoğlu (2003, s. 15) çalışmasında, çocuklarla bireysel olarak gerçekleştirilen sosyal beceri eğitiminin çocukların karşısındakini dinleme, sözlü olarak duygu ve düşüncelerini açılama gibi becerilerinde artışın gözlemlendiğine dair sonuçlara ulaşmıştır. Teglasi ve Rothman (2001, s. 12), geliştirdikleri doğa programında, sosyal beceriler açısından desteğe gereksinim duyan çocukların doğada uzun süre planlı ve plansız vakit geçirmelerini sağlamışlar ve çalş̧manın sonucunda çocukların problem davranışlarının azaldığı ve çocukların davranışlarını kontrol etmeyi öğrendiğini saptamışlardır. Frey, Nolen, Edstrom ve Hirschstein tarafindan 2005 yılında hazırlanan doğa temelli bir sosyal beceri eğitim programında, çocukların özerk bireyler olarak yetiştiklerini ve ciddi oranda problem davranışlarında azalma olduğu saptanmıştır. Ayrıca kızların birbirleri arasında sözel zorbalı̆̆ bırakarak daha fazla işbirliğine yöneldikleri sonucuna da ulaşılmışır. Genel olarak çocukların problem davranışlarının azaltılması ve sosyal becerilerinin artırılması konularında, eğitim ortamı olarak açık alan, doğa veya en azından bahçede gerçekleştirilen etkinliklerin olumlu etkilerine ilişkin kısıtlı sayıda çalışma olduğu görülmektedir. Bu nedenle, bu çalışmada çocukların gelişimlerini en iyi şekilde destekleyecek nitelikli uyarıcıların olduğu, ilgi ve merak uyandıran bir okul bahçesinde gerçekleştirilen etkinliklerin çocukların sosyal becerilerine ve problem davranışlara anlamlı bir etkisi olup olmadığının incelenmesi amaçlanmıştır. Bu doğrultuda araştırmanın temel problem cümlesini "Bahçede gerçekleştirilen etkinlikler, okul öncesi dönemdeki çocukların problem davranışları ve sosyal becerilerini etkilemekte midir?" oluşturmuştur. Alt problemler ise aşağılda verilmiştir:

1. Bahçede gerçekleştirilen etkinlikler öncesi deney ve kontrol grubunun problem davranışları ve sosyal becerileri nasıldır?

2. Bahçede gerçekleştirilen etkinlikler sonrası deney ve kontrol grubunun problem davranışları ve sosyal becerileri nasıldır?

3. Bahçede gerçekleştirilen etkinlikler öncesi ve sonrası deney ve kontrol grubunun problem davranışları ve sosyal becerileri arasında anlamlı fark var mıdır?

4. Bahçede gerçekleştirilen etkinliklerin deney grubunun problem davranışları ve sosyal beceri puan erişilerinin kalıcılığı nasıldır?

\section{Yöntem}

\section{Araştırma Modeli}

Araştırmada ön test-son test, kontrol gruplu yarı deneysel desen kullanılmıştır. Yarı deneysel desen çalışmaları çalışma grubunun rastgele seçilemediği, deney ve kontrol gruplarının olduğu ve deneysel uygulamanın yapıldığı çalışmalardır (Yıldırım ve Şimşek, 2003). Eğitim araştırmalarında araştırmacıların gerçek deneysel çalışmalar yapmaları çoğunlukla mümkün olmadığından sık sık yarı deneysel desen kullanilır. 


\section{Çalışma Grubu}

Çalışma grubunun belirlenmesinde, birbirinden farklı iki durumun olduğu amaçlı örnekleme yöntemlerinden aykırı durum örneklemeden yararlanılmıştır (Büyüköztürk vd., 2012). Çalışmada aykırı durum örneklemeye uygun olarak açk alana sahip olan ve olmayan iki okul öncesi eğitim kurumu belirlenmiştir. Ankara İli’nde Aile ve Sosyal Politikalar Bakanlığı bünyesinde eğitim veren bu okullardan bahçesi olan anaokulundaki çocuklar deney grubuna, bahçesi olmayıp bir apartman katında bulunan anaokulundaki çocuklar kontrol grubuna atanmıştır. Böylece 48-72 aylık 19 kız ve 21 erkek olmak üzere 40 çocuktan 10 kız ve 10 erkek 20 çocuk deney grubunda, 9 kız ve 11 erkek kontrol grubunda yer almıştır.

\section{Veri Toplama Araçları}

Çalışmada Kişisel Bilgi Formu ile çocukların sosyal beceri düzeylerini ve problem davranışlarını belirlemek amacıyla Okul Öncesi ve Anasınıfı Davranış Ölçekleri (OÖDÖ) kullanılmıştır.

Kişisel Bilgi Formu. Çocuklar ve aileleri hakkında bilgi almak amacıyla araştırmacı tarafından oluşturulan formdur.

Okul Öncesi ve Anasımfı Davranış Ölģekleri (OÖDÖ). ABD'de Merrell (1994) tarafindan geliştirilmiştir ve 3-6 yaş arasındaki okul öncesi çocuklarının sosyal beceri ve problem davranışlarını değerlendirmek için kullanılmaktadır. OÖDÖ Sosyal Beceri Ölçeği (SBÖ) ve Problem Davranış Ölçeği (PDÖ) olmak üzere iki ayrı ölçekten oluşmaktadır. Türkçeye uyarlama çalışması Poyraz Tüy (1999) tarafından yapılan ölçeğin çeviri işlemlerinin ardından kapsam geçerliği uzman görüşleriyle sağlanmış ve yapı geçerliği faktör analizi tekniği kullanılarak incelenmiştir. SBÖ, Sosyal Etkileşim, Sosyal Bağımsızlık ve Sosyal İşbirliği olmak üzere üç boyuttan ve 34 maddeden oluşmaktadır. SBÖ’nün Sosyal Etkileşim alt boyutu; başkalarının arkadaşlığını kazanma ve sürdürmenin önemini vurgulayan davranışlan ve özellikleri içeren maddeleri kapsar. Sosyal becerinin yetişkinle ve arkadaşla ilgili boyutunu kapsar. Sosyal Bağımsızlık alt boyutu; arkadaş grubu içinde bağımsızlığı ve başarmayı ölçen maddeleri içerir. Sosyal İşbirliği alt boyutu; arkadaşla uzlaşma ve işbirliği yapma, yetişkinlerin yönergelerine uyma, uygun bir şekilde kendini sınırlamayı vurgulayan özellikleri ve davranıșları yansıtır. PDÖ ise İçselleştirilmiş Problemler ve Dışsallaștırılmış Problemler olarak iki boyut 42 maddeden oluşmaktadır. İçselleştirilmiş Problemler alt boyutu sosyal çekingenlik, kaygı ve somatik problemleri değerlendirmeyi içerir. Dışsallaştırlmış Problemler alt boyutu benmerkezcilik, aşırı hareketlilik, dikkat problemleri, sosyal olmayan ve saldırgan davranışları içerir. Ölçekleri, çocuğun ailesinin veya öğretmenlerinin doldurması gerekmektedir. Ölçekler dörtlü dereceleme ölçeğinden oluşmakta ve sonunda çocukların sosyal beceri ve problem davranışlarına ilişkin dört aşamalı bir işlev düzeyini göstermektedir. Ölçeğin puanlanmasından maddeler "asla" seçeneğinden başlayarak "sık sık” seçeneğine doğru 0 ila 3 arasında değişen değerler almaktadır. SBÖ'den alınan puanın artması çocuğun sosyal beceri düzeyinin yüksek olduğunu, PDÖ’den alınan puanın artması ise çocuğun problem davranışlarının arttığını göstermektedir. Cronbach Alpha iç tutarlılık kat sayısı SBÖ'nün Sosyal İşbirliği alt boyutu için .91, Sosyal Bağımsızlık alt boyu için .71, Sosyal Etkileşim için .71 bulunmuştur. PDÖ'nün alt boyutlarından Dışsallaştırılmış Problemler için.95, İçselleştirilmiş Problemler için .85 olarak belirlenmiştir (Poyraz Tüy, 1999).

\section{Verilerin Toplanması}

Çalışma için gerekli etik izin alınmış, çalısmanın yapılacağı okul yönetimi ve öğretmenleri konu hakkında bilgilendirilmişlerdir. Deney grubundaki çocukların ailelerine bilgi aktarmak için bir toplantı düzenlenmiş, kontrol grubundaki çocukların aileleri yazılı olarak bilgilendirilmiştir. Çalışma grubuna ön testler uygulanmadan önce, ölçekle ilgili karşılaşılabilecek güçlükler ve soruların anlaşılırlığını belirlemek amacıyla iki öğretmen ve iki veliyle ön deneme uygulaması yapmıştır. SBÖ ve PDÖ sınıf öğretmenleri tarafindan, yaz dönemi okulda kalacak çocuklar için doldurulmuştur. Deneysel uygulama 17 Haziran-16 Eylül tarihleri arasında, üç ay süreyle yapılmıştır. Bu süre sonunda SBÖ ve PDÖ son test olarak öğretmenler tarafindan doldurulmuştur. Son test uygulamasından dört hafta sonra, uygulamanın kalıcllığının tespit edilmesi amacıyla deney grubu için SBÖ ve PDÖ tekrar doldurulmuştur.

\section{Verilerin Analizi}

Çalışmada elde edilen veriler bilgisayar ortamına girilmiş ve istatistik programıla analiz edilmiştir. Verilerin deney ve kontrol grubu için normal dağılımdan gelip gelmediği Shpiro-Wilk ile incelenmiştir. Buna göre verilerin analizinde Mann-Whitney-U Testi, Wilcoxon Isşaretli Sıralar Testi ve Spearman Brown korelasyon katsayısından yararlanılmıştır. 


\section{Eğitim Ortamının Düzenlenmesi ve Deneysel Uygulama}

Ön testlerin uygulanmasının ardından, deneysel çalışmanın yapılacağı okulun $800 \mathrm{~m}^{22}$ lik bahçesi okul yönetimi tarafindan düzenlenmiştir. Çocuklar, okulda bulundukları süre zarfinda tüm zamanlarını okul bahçesinde oluşturulan alanlarda geçirmişlerdir. Okul bahçesinde oluşturulan alanlar ve özellikleri aşağıda verilmiştir:

Tuvalet ve lavabo. Tuvalet, el-yüz yıkama gibi ihtiyaçların karşılanması için inşa edilmiştir. İçinde üç tuvalet ve üç lavabonun bulunduğu bu alan, çocukları tuvalet ve temizlik gereksinimlerini karşılamaları için kullanılmıştır.

Piknik alanı. Oyun alanın üst kısmına, çocukların yemeklerini yiyebilecekleri bir piknik alanı yapılmıştır. Piknik alanında ahşap masalar ve oturaklar yanında yerde oturmak isteyen çocuklar için çim alan oluşturulmuştur. Çocuklar sabah kahvaltısı, yemek ve ikindi kahvaltısı öğünlerinde bu alanı kullanmışlardır. Şekil 1'de piknik alanından bir bölüm görülmektedir.

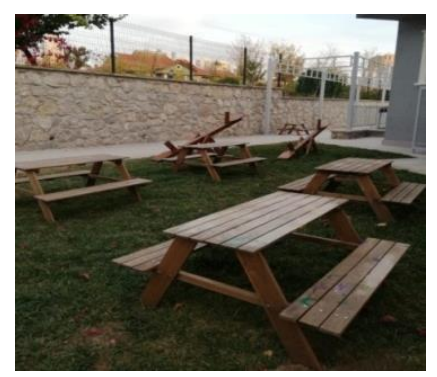

Şekil 1. Piknik. Alan

Dinlenme alanı. Bahçede bulunan ve yeni okula alışma sürecinde çocuklarla beraber dikilen ağaçların altına dinlenme saatleri için minderler yerleştirilmiştir. Uygulama esnasında zaman zaman aileler kamp çadırları da göndermişlerdir.

Sanat alanı. Sanat öğretmeniyle birlikte etkin olarak kullanılabilecek bir sanat alanı oluşturulmuştur. Şekil 2'de bir sanat çalışması ve sergi alanı görülmektedir.

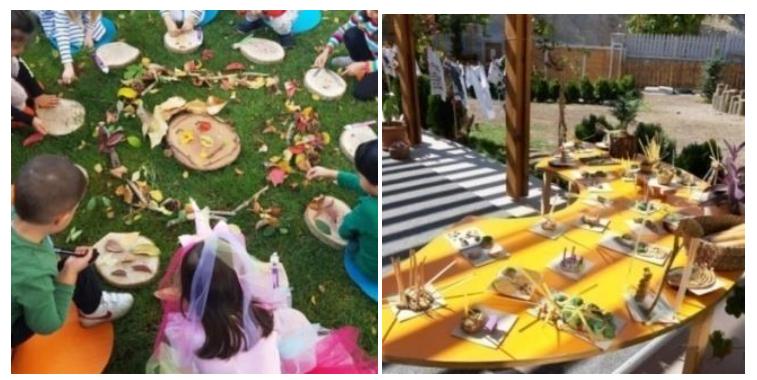

Şekil 2. Sanat Calușması ve Sergi Alanı

Kaba motor beceri alanı. Uzman görüşlerinden de yararlanarak bahçede tırmanma alanı, zıplayan tahterevalli, köstebek tüneli, kaydıraklar, denge tahtası ile bir kaba motor beceri alanı oluşturulmuştur. Şekil 3’te denge tahtası, köstebek tüneli, kaydırak alanı görülmektedir.
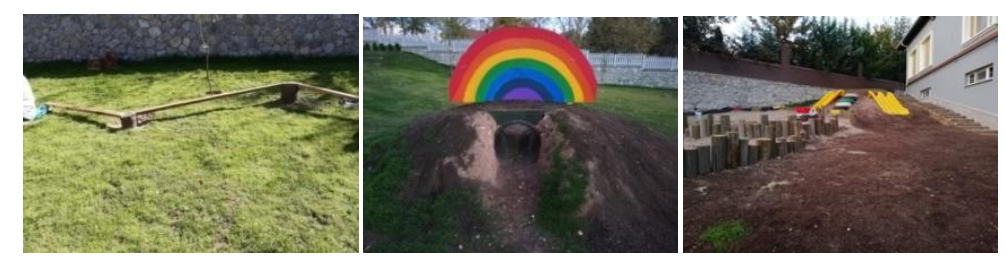

Şekil 3. Denge Tahtası, Köstebek Tüneli ve Kaydırak Alanı

Etkinlik, oyun ve serbest zaman alanları. Çocukların etkinliklerini gerçekleştirebileceği bir çim amfi ve serbest zamanlarda ilgi ve ihtiyaçlarına göre zaman geçirebilecekleri çamur mutfağı, duyu köşesi, küçük bir havuz alanı oluşturulmuştur. Şekil 4'te çamur mutfağı ve çim amfi görülmektedir. 


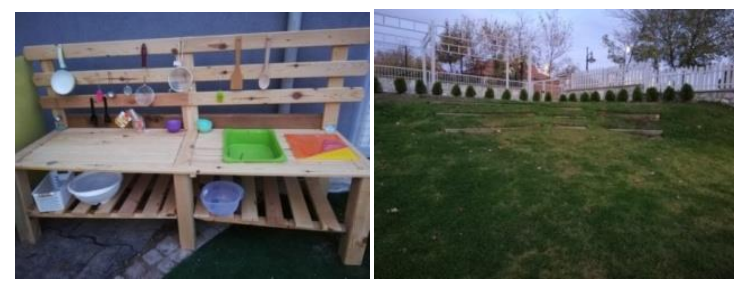

Şekil 4. Çamur Mutfăğ ve Çim Amfi

Deneysel uygulama öncesinde araştırmacı tarafindan grup öğretmeni, sanat öğretmeni, kurum rehberlik servisi, temizlik görevlileri ve mutfak personelinin katıldığı bir toplantı yapılmış ve üç aylık süreyle çocukların okul öncesi eğitim programında yer alan tüm etkinliklerinin bahçede gerçekleştirileceği hakkında konuşulmuştur. Daha sonra ise önce çocukların sürece hazırlanması daha sonra velilerin yaşayabileceği kaygılara karşı önlemler alınmıştır. Uygulama süresince haftada bir toplantı gerçekleștirilmesi planlanmıştır. Kurum, daha önceden her mevsim en az üç gün açı alanda vakit geçirdiği için personelin, velilerin ve çocukların fazlasıyla yadırgadığı bir durum olmamışır.

Ortamın ve kişilerin hazırlığının ardından araştırma kapsamında çocukların açık alanda geçirecekleri üç aylık sürenin planı, aylık kazanım ve göstergelerine göre sınıf içi etkinlikleri açık alana uyarlamak amaçlanmışır. Grup öğretmeni ve araştırmacı tarafindan etkinliklerin uyarlanma sürecinde öncelikle literatür taraması yapılmıştır. Millî Eğitim Bakanlığı Okul Öncesi Eğitim Genel Müdürlüğü 36-72 aylık çocuklar için okul öncesi eğitim programında yer alan kazanım ve göstergelere göre hazırlanan etkinlik planları bahçede uygulanacak şekilde yapılmıştır. Hazırlanan planlar ve etkinlikler, alan uzmanı bir öğretim elamanı tarafindan uygulamanın amacına, çocukların yaş gelişim özelliklerine uygunluğu açısından incelenmiştir. Deneysel uygulama kapsamında hazırlanan etkinliklerin çocukların doğal ortamda yaparak yaşayarak öğrenmesine olanak sağlamasına ve merak unsurları barındırmasına dikkat edilmiştir.

Uygulama boyunca, uygulamalar gözlenmiş ve yaşanan olumlu ve olumsuz bazı durumlar yapılan toplantılarda değerlendirilerek gerekli düzenlemeler yapılması yoluna gidilmiştir. Örneğin; deneysel uygulamanın ilk haftasında çocuklar küçük grup etkinliği için farklı bölümlerde bulunduğu bir zaman diliminde, bir çocuk bahçe kapısından kaçma girişiminde bulunduğundan güvenlik görevlisine gereksinim duyulmuştur. İlk hafta çocuklarla bahçe kuralları, oyun alanlarının işlevleri konuları hakkında sık sık bilgilendirme yapmaya özen gösterilmiştir. Uygulamanın ikinci haftasında ise çocukların bahçedeki ağaçları merak ettikleri gözlemlenmiştir. İkinci haftanın sonunda yapılan toplantı ile çocukların sanat öğretmeniyle birlikte ağaçlara ahşap meyve etiketi yapılması kararı alınmıştır. Aynı zamanda çocukların yaşadığı bahçe kazaları da bu toplantı da değerlendirilmiştir. İlkyardım sertifikası olan sorumlu öğretmene, anında müdahale edebilmesi için küçük bir ilkyardım çantası hazırlanmıştır. İlerleyen haftalarda yapılan toplantılarda yaşanan sorunlar veya kazalar yerine çocuklardaki olumlu değişimler üzerine konuşulmuştur.

$\mathrm{Bu}$ uygulama çocuklarla yaz döneminde gerçekleştirildiğinden hava şartlarından dolayı büyük problemler yaşanmamıştır. Sıcaklığın çok yüksek olduğu Temmuz-Ağustos aylarında dahi çocuklar okul binasına girmemişler, bahçede bulunan kamp çadırlarında veya bahçeye çok amaçlı kullanım doğrultusunda kurulan oyun evi içerisinde dinlenerek vakit geçirmişlerdir. Bu çalışmanın kışın yapılması durumunda da kışlık kamp çadırları ve yağmur-kar kıyafetleri kullanılabileceği öngörülmüştür. Bu konuya açılılk getirebilmek için deneysel uygulamanın ardından, uygulamanın yapıldığı okulda kış mevsiminde bir haftalık bir gözlem yapılmıştır. Kış mevsimindeki soğuk hava ve buzlanma gibi nedenlerle çocukların bahçede en fazla yarım saat kalabildikleri gözlemlenmiştir. Bahçeye çıkma zamanı tüm gün değil bahçe saati şeklinde uygulanmaya devam etmiştir. 


\section{Bulgular}

Tablo 1'de kontrol ve deney grubunun PDÖ ve SDÖ ön test puanları analiz sonuçları, Tablo 2'de ise kontrol ve deney grubu PDÖ ve SDÖ son test puanları arasında fark olup olmadı̆̆ına ilişkin sonuçlar verilmiştir.

Tablo 1. Kontrol ve Deney Grubu PDÖ ve SDÖ Ön Test Puanlar Analiz Sonuclar

\begin{tabular}{|c|c|c|c|c|c|c|}
\hline & Grup & $\bar{N}$ & $\overline{\bar{x}}$ & $S$ & M.W.U & $\bar{p}$ \\
\hline PDÖ İçsel & Kontrol & 19 & 6,0 & 5,134 & 1,373 & 0,170 \\
\hline Problemler & Deney & 20 & 4,0 & 3,817 & & \\
\hline PDÖ Dışsal & Kontrol & 19 & 7,3 & 8,596 & $-1,522$ & 0,128 \\
\hline Problemler & Deney & 20 & 12,5 & 13,020 & & \\
\hline SDÖ Sosyal & Kontrol & 19 & 9,8 & 4,232 & $-1,190$ & 0,241 \\
\hline Etkileşim & Deney & 20 & 11,3 & 3,388 & & \\
\hline SDÖ Sosyal & Kontrol & 19 & 20,7 & 7,275 & $-2,062$ & 0,039* \\
\hline Bağımsızlık & Deney & 20 & 24,9 & 5,087 & & \\
\hline \multirow{2}{*}{ SDÖ Sosyal İşbirliği } & Kontrol & 19 & 23,0 & 5,933 & $-1,276$ & 0,202 \\
\hline & Deney & 20 & 24,6 & 7,534 & & \\
\hline
\end{tabular}

Tablo 1 incelendiğinde, kontrol ve deney grubu PDÖ İçselleştirilmiş Problemler ve Dişsallaştırlmış Problemler ile SDÖ Sosyal Etkileşim ve Sosyal İşbirliği ön test puanları arasındaki fark anlamsızen $(p>0,05)$ SDÖ Sosyal Bağımsızlık ön test puanları arasındaki fark anlamlıdır $(p<0,05)$. Deney grubu SDÖ Sosyal Bağımsızlık ön test puan ortalaması $(\bar{x}=24,9)$, kontrol grubunun puan ortalamasindan $(\bar{x}=20,7)$ anlamlı düzeyde yüksektir. Deney ve kontrol grubunun deneysel çalışma öncesinde PDÖ İçsel ve Dışsal Problemler, SDÖ Sosyal Etkileşim ve Sosyal İşbirliği puanlarının birbirlerine yakın düzeyde olduğu; deney grubunun SDÖ Sosyal Bağımsızlık alt boyut puanlarının ise kontrol grubundan daha yüksek olduğu söylenebilir.

Tablo 2. Kontrol ve Deney Grubu PDÖ ve SDÖ Son Test Puanlar Analiz. Sonuclar

\begin{tabular}{|c|c|c|c|c|c|c|}
\hline & Grup & $N$ & $\overline{\boldsymbol{x}}$ & $S$ & $M . W . U$ & $p$ \\
\hline \multirow{2}{*}{ PDÖ İçsel Problemler } & Kontrol & 19 & 7,3 & 7,498 & \multirow[t]{2}{*}{$-5,137$} & \multirow[t]{2}{*}{$0,000^{*}$} \\
\hline & Deney & 20 & 0,3 & 1,565 & & \\
\hline \multirow{2}{*}{$\begin{array}{l}\text { PDÖ Dişsal } \\
\text { Problemler }\end{array}$} & Kontrol & 19 & 14,9 & 12,195 & \multirow[t]{2}{*}{$-4,498$} & \multirow[t]{2}{*}{$0,000^{*}$} \\
\hline & Deney & 20 & 0,9 & 3,059 & & \\
\hline \multirow{2}{*}{ SDÖ Sosyal Etkileşim } & Kontrol & 19 & 11,0 & 3,300 & \multirow[t]{2}{*}{$-4,981$} & \multirow[t]{2}{*}{$0,000^{*}$} \\
\hline & Deney & 20 & 14,7 & 0,638 & & \\
\hline \multirow{2}{*}{$\begin{array}{l}\text { SDÖ Sosyal } \\
\text { Bağımsızlık }\end{array}$} & Kontrol & 20 & 23,3 & 6,554 & \multirow[t]{2}{*}{$-4,920$} & \multirow[t]{2}{*}{$0,000^{*}$} \\
\hline & Deney & 20 & 29,4 & 1,818 & & \\
\hline \multirow{2}{*}{ SDÖ Sosyal İşbirliği } & Kontrol & 20 & 24,9 & 6,560 & \multirow[t]{2}{*}{$-4,115$} & \multirow[t]{2}{*}{$0,000^{*}$} \\
\hline & Deney & 20 & 29,7 & 1,128 & & \\
\hline
\end{tabular}

Tablo 2'ye göre, deney ve kontrol grubu PDÖ ve SDÖ alt boyutları son test puanları arasındaki fark anlamlıdır $(\mathrm{p}<0,05)$. Kontrol grubu PDÖ İçsel ve Dışsal Problemler alt boyut son test puanları $(\bar{x}=7,3$; $\bar{x}=14,9)$, deney grubunun ortalama puanlarından $(\bar{x}=03 ; \bar{x}=0,9)$ anlamlı düzeyde yüksektir. Kontrol grubunun SDÖ Sosyal Etkileşim, Sosyal Bağımsızlık ve Sosyal İşbirliği son test ortalama puanları ( $\bar{x}=11,0$; $\bar{x}=23,3 ; \bar{x}=24,9)$, deney grubunun ortalama puanlarından $(\bar{x}=14,7 ; \bar{x}=29,4 ; \bar{x}=29,7)$ anlamlı düzeyde daha düşüktür. Kontrol grubunun deneysel uygulama sonrasında PDÖ İçsel ve Dışsal Problemler alt boyut puanları daha yüksek iken SDÖ Sosyal Etkileşim, Sosyal Bağımsızlık ve Sosyal İşbirliği puanlarının deney grubundan daha düşük olduğu görülmektedir.

Tablo 3'te kontrol grubu ve Tablo 4'te deney grubu ön test-son test puanları analiz sonuçları verilmiştir. 
ŞIRIN KAYA ve ÖZYÜREK

Bahçede Uygulanan Okul Öncesi Ĕ̆itimin Çocukların Problem Davranışlarına ve Sosyal Becerilerine Etkisi

Tablo 3. Kontrol Grubu Ön Test-Son Test Puanlar Wilcoxon İsaretli Siralar Testi Sonuclarn

\begin{tabular}{lllcccc}
\hline & Kontrol Grubu & $\boldsymbol{N}$ & $\overline{\boldsymbol{x}}$ & $\boldsymbol{S}$ & $\boldsymbol{z}$ & $\boldsymbol{p}$ \\
\hline \multirow{2}{*}{ PDÖ İçsel Problemler } & Ön Test & 20 & 6,0 & 5,134 & $-0,569$ & 0,569 \\
& Son Test & 20 & 7,3 & 7,498 & & \\
\hline \multirow{2}{*}{ PDÖ Dişsal Problemler } & Ön Test & 20 & 7,3 & 8,596 & $-1,849$ & 0,064 \\
& Son Test & 20 & 14,9 & 12,195 & & \\
\hline \multirow{2}{*}{ SDÖ Sosyal Etkileşim } & Ön Test & 20 & 9,8 & 4,124 & $-1,025$ & 0,305 \\
& Son Test & 20 & 11,0 & 3,300 & & 0,191 \\
\multirow{2}{*}{ SDÖ Sosyal Bağımsızılık } & Ön Test & 20 & 20,7 & 7,275 & $-1,308$ & \\
& Son Test & 20 & 23,3 & 6,554 & & \\
\hline \multirow{2}{*}{ SDÖ Sosyal İşbirliği } & Ön Test & 20 & 23,0 & 5,933 & $-0,619$ & 0,536 \\
& Son Test & 20 & 23,9 & 6,560 & & \\
\hline
\end{tabular}

Tablo 3'e göre, kontrol grubunun PDÖ ve SDÖ tüm alt boyutları ön test-son test puanları arasındaki fark anlamlı değildir ( $\mathrm{p}>0,05)$. Deneysel uygulama öncesinden sonrasına, geçen zaman içerisinde kontrol grubunun PDÖ ve SDÖ alt boyut puanlarında anlamlı bir değişiklik olmadığı söylenebilir.

Tablo 4. Deney Grubu PDÖ ve SDÖ Ön Test-Son Test Puanlar Wilcoxon Işsaretli Siralar Testi Sonuclar

\begin{tabular}{|c|c|c|c|c|c|c|}
\hline & Deney Grubu & $\mathbf{N}$ & $\overline{\bar{x}}$ & $S$ & $\bar{z}$ & $p$ \\
\hline \multirow{2}{*}{ PDÖ İçsel Problemler } & Ön Test & 20 & 4,0 & 3,817 & $-3,636$ & $0,000^{*}$ \\
\hline & Son Test & 20 & 0,3 & 1,565 & & \\
\hline \multirow{2}{*}{ PDÖ Dışsal Problemler } & Ön Test & 20 & 12,5 & 13,020 & $-3,929$ & $0,000 *$ \\
\hline & Son Test & 20 & 0,9 & 3,059 & & \\
\hline \multirow{2}{*}{ SDÖ Sosyal Etkileşim } & Ön Test & 20 & 11,3 & 3,388 & $-3,637$ & $0,000 *$ \\
\hline & Son Test & 20 & 14,7 & 0,638 & & \\
\hline \multirow{2}{*}{ SDÖ Sosyal Bağımsızlık } & Ön Test & 20 & 24,9 & 5,087 & $-3,638$ & $0,000 *$ \\
\hline & Son Test & 20 & 29,4 & 1,818 & & \\
\hline \multirow{2}{*}{ SDÖ Sosyal İşbirliği } & Ön Test & 20 & 24,6 & 7,534 & $-2,936$ & $0,000 *$ \\
\hline & Son Test & 20 & 29,7 & 1,128 & & \\
\hline
\end{tabular}

Tablo 4'e göre, deney grubu PDÖ ve SDÖ ön test-son test puanları arasindaki fark tüm alt boyutlarda anlamlıdır $(\mathrm{p}<0,05)$. Deney grubu PDÖ İçsel Problemler ve Dışsal Problemler ön test puan ortalaması $(\bar{x}=4,0 ; \bar{x}=12,5)$, son test puan ortalamalarından $(\bar{x}=0,3 ; \bar{x}=0,9)$ anlamlı düzeyde yüksektir. SDÖ Sosyal Etkileşim, Sosyal Bağımsızlık ve Sosyal İşbirliği ön test ortalama puanları $(\bar{x}=11,3 ; \bar{x}=24,9 ; \bar{x}=24,6)$ son test ortalama puanlarından $(\bar{x}=12,7 ; \bar{x}=29,4 ; \bar{x}=29,7)$ anlamlı düzeyde düşüktür. Deneysel uygulama öncesinden sonrasına deney grubunun PDÖ İçsel ve Dışsal Problemler alt boyut puanlarında anlamlı düzeyde düşme, SDÖ Sosyal Etkileşim, Sosyal Bağımsızlık ve Sosyal İşbirliği alt boyut puanlarından anlamlı düzeyde artış olduğu söylenebilir.

Tablo 5’te deney grubu PDÖ ve SDÖ son test-kalıcılık testi puanları analiz sonuçları verilmiştir.

Tablo 5. Deney Grubu PDÖ ve SDÖ Son Test-Kahcullk Testi Puanlar Wilcoxon İsaretli Siralar Testi Sonuclar

\begin{tabular}{|c|c|c|c|c|c|c|}
\hline & Deney Grubu & $N$ & $\overline{\bar{x}}$ & $S$ & $\bar{z}$ & $p$ \\
\hline PDÖ İçsel & Son Test & 20 & 0,3 & 1,565 & $-2,650$ & $0,008^{*}$ \\
\hline Problemler & Kalıcilik Testi & 20 & 1,4 & 1,394 & & \\
\hline PDÖ Dışsal & Son Test & 20 & 0,9 & 3,059 & $-3,407$ & $0,001 *$ \\
\hline Problemler & Kalıcılık Testi & 20 & 5,0 & 3627 & & \\
\hline SDÖ Sosyal & Son Test & 20 & 14,7 & 0,638 & $-3,438$ & 0,001* \\
\hline Etkileşim & Kalıcılık Testi & 20 & 12,7 & 1,292 & & \\
\hline SDÖ Sosyal & Son Test & 20 & 29,4 & 1,818 & $-2,606$ & $0,009 *$ \\
\hline Bağımsızlık & Kalıcılık Testi & 20 & 27,4 & 2,583 & & \\
\hline \multirow{2}{*}{ SDÖ Sosyal İşbirliği } & Son Test & 20 & 29,7 & 1,128 & $-3,850$ & $0,000^{*}$ \\
\hline & Kalıcılık Testi & 20 & 24,5 & 2,762 & & \\
\hline
\end{tabular}

Tablo 5'e göre, deney grubu PDÖ ve SDÖ son test-kalıcıllk testi puanları arasındaki fark tüm alt boyutlarda anlamlıdır $(\mathrm{p}<0,05)$. Deney grubunun PDÖ İçsel Problemler ve Dişsal Problemler son test puan ortalaması $(\overline{\mathrm{x}}=0,3 ; \overline{\mathrm{x}}=0,9)$, kalıcllı testi puan ortalamalarından $(\overline{\mathrm{x}}=1,4 ; \overline{\mathrm{x}}=5,0)$ anlamlı düzeyde düşüktür. SDÖ Sosyal Etkileşim, Sosyal Bağımsızlık ve Sosyal İşbirliği son test ortalama puanları ( $\bar{x}=14,7$; $\bar{x}=29,4 ; \bar{x}=29,7)$ kalıcllık testi ortalama puanlarından $(\bar{x}=12,7 ; \bar{x}=27,4 ; \bar{x}=24,5)$ anlamlı düzeyde yüksektir. Deneysel uygulama tamamlandıktan ve çocuklar okul binası içinde eğitimlerine devam etmeye başladıktan 
4 hafta sonrasında deney grubunun PDÖ İçsel ve Dışsal Problemler alt boyut puanlarında anlamlı düzeyde artış, SDÖ Sosyal Etkileşim, Sosyal Bağımsızlık ve Sosyal İşbirliği alt boyut puanlarından anlamlı düzeyde azalma olduğu söylenebilir.

Tablo 6'da çalışma grubundaki çocukların PDÖ ve SDÖ ön test-son test puanları arasındaki korelasyon analizi sonuçları verilmiştir.

Tablo 6. Okul Öncesi Cocuklarn PDÖ ve SDÖ Ön Test-Son Test Puanlarn Arasindaki Korelasyon

\begin{tabular}{|c|c|c|c|c|c|c|}
\hline & \multirow[b]{2}{*}{$S D \ddot{O}$} & & \multicolumn{2}{|c|}{ Ön Test } & \multicolumn{2}{|c|}{ Son Test } \\
\hline & & & $\begin{array}{l}\text { PDÖ İçsel } \\
\text { Problemler }\end{array}$ & $\begin{array}{l}\text { PDÖ Dişsal } \\
\text { Problemler }\end{array}$ & $\begin{array}{l}\text { PDÖ İçsel } \\
\text { Problemler }\end{array}$ & $\begin{array}{l}\text { PDÖ Dişsal } \\
\text { Problemler }\end{array}$ \\
\hline \multirow{6}{*}{ Ön Test } & \multirow{2}{*}{ Etkileşim } & $\mathrm{r}$ & $-0,273$ & $-0,167$ & & \\
\hline & & $\mathrm{p}$ & 0,093 & 0,310 & & \\
\hline & \multirow{2}{*}{ Bağımsızlık } & $\mathrm{r}$ & $-0,487$ & 0,053 & & \\
\hline & & $\mathrm{p}$ & $0,002^{*}$ & 0,747 & & \\
\hline & \multirow{2}{*}{ İşbirliği } & $\mathrm{r}$ & $-0,286$ & $-0,290$ & & \\
\hline & & $\mathrm{p}$ & 0,078 & 0,074 & & \\
\hline \multirow{6}{*}{ Son Test } & \multirow{2}{*}{ Etkileşim } & $\mathrm{r}$ & & & $-0,711$ & $-0,560$ \\
\hline & & $\mathrm{p}$ & & & $0,000^{*}$ & $0,000^{*}$ \\
\hline & \multirow{2}{*}{ Bağımsızlık } & $\mathrm{r}$ & & & $-0,802$ & $-0,560$ \\
\hline & & $\mathrm{p}$ & & & $0,000^{*}$ & $0,000^{*}$ \\
\hline & \multirow{2}{*}{ İşbirliği } & $\mathrm{r}$ & & & $-0,646$ & $-0,569$ \\
\hline & & $\mathrm{p}$ & & & $0,000^{*}$ & $0,000^{*}$ \\
\hline
\end{tabular}

Tablo 6 incelendiğinde, kontrol ve deney grubundaki okul öncesi çocukların PDÖ ve SDÖ ön test puanları karşılaştırıldığında PDÖ İçsel Problemler alt test puanlarıyla SDÖ ön test puanları arasında istatistiksel olarak orta düzeyde anlamlı negatif bir ilişki; son test puanları karşılaştırıldığında ise PDÖ İçsel ve Dışsal Problemler ile SDÖ Etkileşim, Bağımsızlık ve İşbirliği alt test puanları arasında yüksek düzeyde anlamlı negatif bir ilişki olduğu görülmektedir $(p<0,05)$. Ön test puanları dikkate alındığında çocukların PDÖ İçsel Problemler alt boyut puanları arttıkça SDÖ Bağımsızlık alt boyut puanları azalmakta; son test puanları dikkate alındığında çocukların PDÖ puanları arttıkça SDÖ puanları azalmakta veya PDÖ puanları azaldıkça SDÖ puanları da artmaktadır. Buna göre, okul öncesi çocukların problem davranışları arttıkça sosyal becerilerinin azaldığı veya sosyal becerileri azaldıkça problem davranışlarının arttığı söylenebilir.

\section{Tartışma, Sonuç ve Öneriler}

$\mathrm{Bu}$ çalışmada, okul öncesi 4-6 yaş grubu çocukların okul öncesi etkinliklerinin bahçede gerçekleştirilmesinin çocukların problem davranışları ve sosyal becerilerine etkisi incelenmiştir. Çalışmanın başlangıcında kontrol ve deney grubu problem davranış ve sosyal beceriler yönünden birbirine yakın özellikler gösterdiği görülmüştür. Üç aylık sürede kontrol grubu bahçesi olmayan okulda, bina içinde eğitimine devam ederken deney grubu tüm günü bahçede geçirmiştir. Deney grubunun bireysel, grup veya rutin etkinlikleri bahçe ortamında yürütülmüştür.

Çalışmadan elde edilen ilk sonuç, okul öncesi eğitim etkinliklerinin bahçede gerçekleştirilmesinin, çocukların sosyal becerilerini anlamlı düzeyde artırdığı olmuştur. Yani okul öncesi dönemde kazanılması gereken sosyal ortamda bağımsız hareket edebilme, sosyal ortamın gereksinimlerini algılama ve doğru yorumlama, sosyal ortama uygun davranma gibi becerilerin açık alanda geçirilen sürede çocuklarda gözlemlendiği görülmüştür. Çalışmadan elde edilen diğer sonuç ise okul öncesi eğitim etkinliklerinin bahçede gerçekleştirilmesinin, çocukların problem davranışlarını anlamlı düzeyde azalttığı olmuştur. Buna göre; çocukların yüksek yararı ve gelişimsel özellikleri göz önünde bulundurularak düzenlenmiş bir bahçede gerçekleştirilen etkinliklerin, çocuklarda sosyal becerileri artırarak problem davranışların azalmasına etki ettiği sonucuna varılmıştır. Benzer bir çalışmada Ay, Anagün ve Demir (2015, s. 103), dış mekânda gerçekleştirilen aktif öğrenme etkinliklerinin çocukların, bilişsel ve sosyal becerilerine katk1 sağladığını ortaya koymuşlardır.

Doğası gereği her çocuk açık alanda olmaktan hoşnut olur. Okul bahçesinde yapılan etkinliklere katılım sağlayan çocuk kendi içsel motivasyonuna göre bir ilgi alanı bulabilir, ilgi alanıyla uğraşırken rahatlar ve iç kontrol kazanmaya başlayabilir. İç rahatlama yaşayan ve kendi uğraşına odaklanan çocuk, problem oluşturabilecek durumlardan uzak kaldığ gibi kendi problemlerini kendisi çözme deneyimi edinebilir. Açık alanda yapılan etkinliklerin, çocukların davranışları yanında bilişsel gelişimlerini de 
etkilediği yapılan çalışmalarla ortaya konmuştur (Balım vd., 2013; Civelek ve Akamca, 2017). Etkinliklerin açık havada gerçekleştirilmesi çocuklarnn dikkatini yoğunlaştırırken çevredeki pek çok şeyi fark etmesine, planlama, problem çözme, karar verme, gözlem yapma, sosyal etkileşimlerde bulunma firsatı sunar (Burdette ve Whitaker, 2005, s. 657; White, 2004, s. 130). Arabac1 ve Çıtak (2017, s. 28) yapt1klar1 çalışmada açık alanda gerçekleştirilen etkinliklere 3-6 yaş arasındaki tüm çocukların büyük ilgi gösterdiklerini belirtmişlerdir. Çocukların bu ilgileri sayesinde açık alanda oynadıkları birbirinden yaratıcı oyunlarla bilişsel, fiziksel, sosyal ve duygusal hatta öz bakım becerilerinin de desteklendiği sonucuna ulaşmışlardır. Bu araştırmaların, çalışma bulgularıyla paralellik gösterdiği söylenebilir. Çocuklar bahçede geçirdikleri zaman sürecinde, ögretmen rehberliğindeki grup etkinlikleri yanında küçük grup veya bireysel etkinliklerle, çevredeki ağaçlar veya böcekler gibi canlıları gözlemleme, doğal materyallerle sınıflama, gruplama, tahmin veya eşleştirme gibi oyun temelli somut deneyimler edinme firsatı bulmuşlardır. Bu somut deneyimlerin, çocukların eğlenerek öğrenme yanında olumlu benlik algısı geliştirmelerine katkı sağladığı düşünülebilir.

Deneysel çalışma süresi bittiğinde çocuklar okul binası içinde eğitimlerine devam etmişlerdir. Eğitim öğretimin sınıf içinde gerçekleştirilmeye başlandığı zaman diliminde yapılan kalıcılık testi sonuçları, çocukların problem davranışlarında artış ve sosyal becerilerinde azalma olduğunu göstermiştir. Bu sonuç, çocuğun gelişiminin desteklenmesinde uygun ortamın oldukça önemli bir yere sahip olduğunu göstermektedir. Alan yazında, çalışmadan elde edilen bu sonucu destekleyen bilgilere rastlamak mümkündür. Yavuzer (2005, s. 50) çocukların zihinsel, fiziksel ve duygusal ihtiyaçlarının en iyi şekilde açı havada oynanan oyunlarla karşılandığına dikkat çekmektedir. Dış mekânlar çocukların gelişiminin desteklenmesinde ve eğitim programının hedefe ulaşmasında önemli bir öğedir (Berk ve Winsler, 1995, s. 236). Bu açıdan bakıldığında çocukların gelişimlerinin desteklemek için yapılan eğitim uygulamalarında açık alanların gerekliliği anlaşılmaktadır. Ancak gelişen, değişen ve günden güne şehirleşen dünyada çocukların dış mekân gereksinimlerini karşılayan açık alanlar okul bahçeleri olmaya başlamıştır. Okul bahçeleri, çocukların motor gelişimlerinin yanı sıra bilişsel ve sosyal becerilerinin gelişiminde de önemli bir yere sahiptir (Tepebağ ve Aktaş Arnas, 2017, s. 50).

Çocukluk döneminde doğadan uzak olmak, fiziksel veya zihinsel sağlı̆ı olumsuz etkilemesinin yanı sıra bireyin doğayı anlama ve koruma bilincini de olumsuz yönde etkilemektedir. Louv (2005, s. 70), artık gençlerin ve hatta çocukların obezite, uyuşturucu madde kullanımı, dikkat eksikliği gibi birçok fiziksel ve ruhsal sağlık sorununun açı alanlarda/doğal çevrelerde yeterli zaman geçirilmemesinin bir sonucu olduğunu belirtmektedir. Sağlıklı bireyler ve sağlıklı bir toplum oluşturmak isteniyorsa, özellikle 0-6 yaşta çocukların doğal çevrelerde zaman geçirmesini sağlamak son derece önemlidir (White, 2004, s. 130). Okul öncesi dönemde pek çok beceri ve alışkanlık kazanılmaktadır. Bu beceri ve alıskanlıkların kazanılması amacıyla eğitimde kalıplaşmış yargılardan uzak olunmalı, eğitim tesadüflere de bırakılmamalıdır (Akdağ ve Erdiller, 2006, s. 100). Açık havada geçirilen sürenin fiziksel, sosyal, bilişsel, duygusal, motor veya dil gelişimi gibi tüm gelişim alanlarına olumlu katk1 sağladığı düşünüldüğünde, okul öncesi yıllardan itibaren, çocukların öğrenme yaşantılarını sınıf dışı ortamlarda edinmesi için çaba gösterilmesi gerektiği söylenebilir.

Sonuç olarak, okul öncesi çocukların gün boyunca dinlenme de dâhil olmak üzere pek çok etkinliği uygun şekilde düzenlenmiş bir bahçede gerçekleştirmesi mümkün görünmektedir. Çocukların bahçede geçirdiği zaman diliminde, sınıf ortamındaki kısıtlı imkânlara göre çok daha fazla deneyim yaşayacağı ve somut materyallerle eğlenerek öğreneceği söylenebilir. Çocuk fazla enerjisini atarken beden ve zihinsel güçlerinin sınırlarını fark eder. Çevresindeki bireylerle daha olumlu ilişkiler kurar ve yetişkinler için problem olarak nitelendirilen pek çok davranışı ortadan kalkar veya azalır. Kısaca, çocukların açık alanda geçirdikleri zaman onlara için sınıf ortamında olduğundan çok daha fazla olumlu kazanımlar sunacaktır.

Yapılan çalışma sonuçları ve alan yazın bilgileri ışığında, aşağıdaki öneriler geliştirilmiştir:

- Çocukların her yaşta, olabildiğince açık alanlarda ve doğal ortamlarda zaman geçirmesine firsat tanınmalıdır. Okul öncesi eğitim kurumları başta olmak üzere diğer eğitim kademelerinde de sınıf dış/ bahçe veya açık alan etkinliklerine daha fazla yer verilebilir. Çocuklar gerek kazanımlara uygun aktiviteleri ve gerekse boş zaman aktivitelerini kum, çim ve toprak alanlarda gerçekleştirebilirler.

- Okul öncesi eğitim programı, açık alan etkinlerine önem verilmesi gerektiğini vurgulamaktadır. Fakat uygulamada hava şartları, velinin çocuğun hasta olmasına ilişkin kaygıları, okulun fiziksel şartlarının uygun olmaması ve öğretmenin kaza vb. nedenler karşısında yaşadığı kaygılar nedeniyle çocuklarla açık alana çıkma süreleri oldukça yetersiz kalmaktadır. Eğitimcilere yönelik olarak okulun mevcut alanlarının kullanılması ve açık alan kullanımına yönelik eğitimler düzenlenebilir. 
- Eğitim ve öğretimin iç mekânlardan dış mekânlara geçmesi için Millî Eğitim Bakanlığı resmi talimatıyla son yıllarda öğretim yılı boyunca iki defa düzenlenen ve çocukların okul dışında zaman geçirmelerine firsat veren "Okul Dışarıda" günü gibi açık alan çalışmaları ayda bir gün, haftada bir gün ve daha sonra haftanın her günü şeklinde uygulanarak kurum, eğitimci, aile ve çocukların uyumu sağlanabilir, uygulama yaygınlaştırlabilir.

- Öğretmenler günlük etkinlikleri, daha sık açık alanda gerçekleştirecek şekilde planlayabilirler. Okul şartları uygun olmadığında ise okul dışındaki park ve bahçe gibi açık alanlardan yararlanabilirler. Bu amaçla okul ve çevresindeki tüm imkânlar kullanılabilir.

- Kurum veya eğitimciler Kızılay, Yeşilay, Tohum Otizm Vakfı gibi sivil toplum kuruluşlarıyla işbirliği yaparak okul bahçelerinde belirli zamanlarda amaca uygun çalışmalar yapabilirler.

- Okul öncesi eğitimde açı alan uygulamalarıyla ilgili örnekler, günümüzün en etkili iletişim aracı sosyal medya aracilığıyla eğitimcilere ve velilere duyurulabilir. Aile eğitimi çalışmalarında açık alanda geçirilen zamanın önemi vurgulanarak, veliler çocuklarıyla açı alanda zamana geçirmeleri için teşvik edilebilir.

- $\mathrm{Bu}$ çalışmada, okul öncesi eğitim programında yer verilen etkinliklerin bahçede gerçekleştirilmesinin çocukların sosyal becerileri ve problem davranışları üzerine etkisi incelenmiştir. Bahçede gerçekleştirilen etkinliklerin çocukların bilimsel süreç becerilerine, problem çözme becerilerine, motor becerilerine, fen ve matematik gelişimine etkisinin inceleneceği çalışmalar yapılabilir. Gözlem ve görüşme gibi nitel veri toplama yöntemleriyle veri toplanabilir.

\section{Etik Beyan}

"Bahşede Uygulanan Okul Öncesi Eğitimin Cocuklarn Problem Davranıslarna ve Sosyal Becerilerine Etkisi”" başliklı çalışmanın yazım sürecinde bilimsel kurallara, etik ve alıntı kurallarına uyulmuş; toplanan veriler üzerinde herhangi bir tahrifat yapılmamış ve bu çalışma herhangi başka bir akademik yayın ortamına değerlendirme için gönderilmemiştir. Gerekli olan etik kurul izinleri Karabük Üniversitesi Sosyal ve Beşeri Bilimler Araştırmaları Etik Kurulu'nun 16.04.2019 tarih ve 2019/07 sayılı toplantısında alınmıştır.

\section{Kaynakça}

Açıkgöz, K. Ü. (2002). Aktif ögrenme. İzmir: Eğitim Dünyası Yayınları.

Akdăg, Z. ve Erdiller, Z. (2006). Okulöncesi eğitim çağındaki çocuklara çevre bilincini kazandırmak için gönüllü kuruluşlar ile işbirliği yapmak. VII. Ulusal Fen Bilimleri ve Matematik Eğitimi Kongresi, 7-9 Eylül, Ankara.

Akkılıç Kansu, N. (2009). Cocuklar ve Doğa. Ekoloji - Cevre Kirliliğ̈ - Yenilenebilir Enerji. Erişim adresi: http://www.ekoloji.biz/cevre-dostlari/cocuklar-ve-doga.html, sitesinden 26.12.2019 tarihinde erişilmiştir.

Akman, B., Baydemir, G., Akyol, T., Arslan, A. Ç. ve Kükütçü, S. K. (2011) Okul öncesi öğretmenlerinin sınıfta karşlasştıkları sorun davranışlara ilişsin düşünceleri. E. Joumal of New World Sciences Academy Education Sciences, 6(2), 1715-1731.

Alisinanoğlu, F. ve Kesicioğlu, O. S. (2010). Okul öncesi dönem çocuklarının davranış sorunlarının çeşitli değişkenler açısından incelenmesi (Giresun ili örneği). Kuramsal Eğitim Bilim Dergisi. Journal of Theoretical Educational Science, 3(1), 0-0.https://dergipark.org.tr/tr/pub/akukeg/issue/29340/313969.

Anlıak, Ş. ve Dinçer, Ç. (2005). Farklı eğitim yaklaşımları uygulayan okul öncesi eğitim kurumlarına devam eden çocukların kişiler arası problem çözme becerilerinin değerlendirilmesi. Ankara Üniversitesi Eğitim Bilimleri Fakïltesi Dergisi, 38(1), 149-166.

Arabacı, N. ve Çııtak, Ş. (2017). Okul öncesi dönemdeki çocukların "oyun" ve "açı alan (bahçe)" etkinlikleri ile ilgili görüslerinin incelenmesi ve örnek bir bahçe düzenleme çalışması. Mediterranean Journal of Educational Research, $11(21), 28-43$.

Avcıoğlu, H. (2003). Okulöncesi dönemdeki çocuklara sosyal becerilerin öğretilmesinde işbirlikçi öğrenme yöntemi ile sunulan öğretim programının etkililiğinin incelenmesi. OMEP Dünya Konsey Toplantısı ve Konferansı, 5-11 Ekim, Kusadası/Türkiye.

Ay, Y., Anagün, Ş. S. ve Demir, Z. M. (2015). Sınıf öğretmeni adaylarının fen öğretiminde okul dışı öğrenme hakkındaki görüşleri. Electronic Turkish Studies, 10(15),103-118.

Balım, A. G. (2013). The effect of mind-mapping applications on upper primary students' success and inquirylearning skills in science and environment education. International Research in Geographical and Environmental Education, 22(4), 337-352.

Başal, H. A. (2005). Cocuklar için uygulamal cevre eğitimi. İstanbul: Morpa.

Berk, L. E. \& Winsler, A. (1995). Scaffolding Children's Learning: Vygotsky and Early Childhood Education. NAEYC Researchin to Practice Series. Volume 7. National Association for the Education of Young Children, 1509 16th Street, NW, Washington, DC 236-1426 (NAEYC Catalog 146). 
Birkan, B. (2002). Çocuklarda davranışsorunları ve başa çıkma yolları. Coluk Çocuk Aylık Anne Baba Eğitimci Dergisi, 17, 18-20.

Burdette, H. L. ve Whitaker, R. C. (2005). A national study of neighborhood safety, outdoor play, television viewing, and obesity in preschool children. Pediatrics, 116(3), 657-662.

Büyüköztürk, Ş., Kılıç Çakmak, E., Akgün, Ö. E., Karadeniz, Ş. ve Demirel, F. (2012). Bilimsel Araştırma Yöntemleri, 11.bask1. Ankara: Pegem Yayıncilık.

Carr, E. G. ve Durand, V. M. (1985). The social communicative basis of severe behavior problems in children (Eds: Reiss ve R. R. Bootzin), The oretical issues in behavior therapy (pp. 219 254). New York: Academic Press.

Ceylan, R. ve Yiğitalp, N. (2018). Aile katılımlı ve aile katılımsız sosyal beceri eğitiminin çocukların sosyal becerilerine etkisi. Anemon Mus Alparslan Üniversitesi Sosyal Bilimler Dergisi, 6(6), 119-1127.

Civelek, P., \& Akamca, G. Ö. (2017). Açık alan etkinliklerinin okul öncesi dönemdeki çocukların bilimsel süreç becerilerine ait kazanımlarının gelişimine etkisi. Electronic Turkish Studies, 12(18).

Çelik, A. (2012). Okul öncesi eğitim kurumlarında açı alan kullanımı: Kocaeli örneği. Atatürk Üniversitesi Ziraat Fakültesi Dergisi, 43(1), 79-88.

Dearing, C. G., Kilburn, S. ve Lindsay, K. S. (2014). Validation of the sperm class analyser CASA system for sperm counting in a busy diagnostic semen analysisla boratory. Human Fertility, 17(1), 37-44.

Derman, M. T. ve Başal, H. A. (2013). Okulöncesi çocuklarında gözlenen davranış problemleri ile ailelerinin annebaba tutumları arasındaki ilişki. Amasya Üniversitesi Eğitim Fakültesi Dergisi, 2(1), 115-144.

Eratay, E. (2011). Okul Öncesi Cocuklarnda Davranıs Problemleri. Education Sciences, 6(3), 2347-2362.

Frey, K. S., Nolen, S. B., Edstrom, L. V. S. ve Hirschstein, M. K. (2005). Effects of a school-based social-emotionalcompetence program: Linking children's goals, attributions and behavior. Journal of Applied Developmental Psychology, 26(2), 171-200.

Gezgin, N. (2009). Okul öncesi eğitimi ögretmenlerinin kullandıklar simf yönetimi stratejileri (Yüksek Lisans Tezi). Uludăg Üniversitesi.

Kandır, A. (2000). Öğretmenlerin beş-altı yaş çocuklarında görülen davranış problemlerine ilişkin bilgi ve tutumları. Gazi Üniversitesi Mesleki Eğitim Fakültesi Dergisi, 2(1), 42-50.

Louv, R. (2005). Nature Deficit. Orion, 70-71 https://www.firenewsroom.org/sites/default/files/Louv-HealthJulAug05.pdf adresinden 25.06.2020 tarihinde erişilmiştir.

Özbey, S. (2010). Okul öncesi çocuklarda uyum ve davranış problemleriyle başa çıkmada ailenin rolü. Sosyal Politika Calıșalar Dergisi, 21(21), 9-18.

Özyürek, A. ve Ceylan, Ş. (2014). Okul öncesi çocuklarda sosyal becerilerin desteklenmesi konusunda öğretmen ve veli görüşlerinin belirlenmesi. Pamukekale Üniversitesi Eğitim Fakültesi Dergisi, 35(1), 99-114.

Poyraz Tüy, S. (1999). 3-6 yas arasindaki işitme engelli ve işiten çocuklarm sosyal beceri ve problem davranıslar yönünden karşılaştırlmalar (Yüksek Lisans Tezi), Ankara: Ankara Üniversitesi Sosyal Bilimler Enstitüsü.

Poyraz, H. ve Dere, H. (2003). Okul öncesi eğitiminin ilke ve yöntemleri. Ankara: Anı Yayıncilık.

Priest, S. (1986). Redefining outdoor education: A matter of many relationships. Journal of Environmental Education, 17(3), 13-15.

Senemoğlu, N. (2001). Öğrenme nasıl olusmaktader. Öğrenmenin Oluşmu. Ankara: MEB. Modül, 1.

Sivri, H. (1993). Fiz̨ikesel ve mekânsal çevrenin çocuk davranıslarna ve gelişimine etkileri-çocuk için olușturulacak çevrelerde tasarmm verilerinin saptanmas. (Doktora Tezi), İzmir: Dokuz Eylül Üniversitesi Fen Bilimleri Enstitüsü.

Strasburger, V. C., Teglasi, H. ve Rothman, L. (2001). Stories a classroom-based program toreduce aggressive behavior. Journal of School Psychology, 39(1), 71-94.

Temel, Z. F. ve Dere, H. (1999). Okul öncesi eğitimde yaklaşımlar. gazi üniversitesi anaokulu/anasinnfi ögretmeni el kitabı. İstanbul: Ya-Pa.

Tepebağ, D. ve Aktaş Arnas, Y. (2017). Okul öncesi öğretmenlerinin okul bahçesini eğitsel amaçlı kullanımına yönelik görüşlerinin incelenmesi. Uluslararası Erken Cocukluk Eğitimi Calısmalar Dergisi, 2(2), 50-67.

Tsai, J. T. (2006). The identification of the components for an outdoor education curriculum in Taiwan (Thesis). Indiana University, USA.

Turney, K. ve McLanahan, S. (2015). The academic consequences of early childhood problem behaviors. Social science research, 54, 131-145.

Uyanık Balat, G., Şimşek, Z. ve Akman, B. (2008). Okul öncesi eğitim alan çocukların davranış problemlerinin anne ve öğretmen değerlendirilmeleri açısından karşılaştırılması. Hacettepe Üniversitesi Ë̆gitim Fakültesi Dergisi, 34(34), 263-275.

Wake, M., Hesketh, K. ve Waters, E. (2003). Television, computeruse and body massindex in Australian primary school children. Journal of Paediatrics and Child Health, 39(2), 130-134.

White, R. (2004). Young children's relationship with nature: Its importance to children's development and the earth's future. https://www.whitehutchinson.com/children/articles/childrennature.shtml.29.08.2020.

Yavuzer, H. (2001). Ë̆itim ve gelişim özellikleriyle okul çă̆ çocuğu (7. Basım). İstanbul: Remzi Yayınevi.

Yavuzer, H. (2005). Doğum öncesinden ergenlik sonuna çocuk psikolojisi. İstanbul: Remzi Yayınevi.

Yıldırım, A. ve Şimşek, H. (2003). Sosyal bilimlerde nitel araștırma yöntemleri. İstanbul: Seçkin Yayıncılık.

Yumuş, M. (2013). Okul öncesi eğitimcilerin 36-72 ay aralğ̆ındaki cocuklarn davranıs problemleri ile ilgili görüslerinin incelenmesi ve başa çıkma stratejilerinin belirlenmesi (Yüksek Lisans Tezi). Hacettepe Üniversitesi Sağlık Bilimleri Enstitüsü, Ankara. 
Zachrisson, H. D. ve Dearing, E. (2015). Family in comedy namics, early childhood education and care, and early child behavior problems in Norway. Child Development, 86(2), 425-440.

\section{EXTENDED ABSTRACT}

Nature is the most effective and natural way that prepares the child for life, increases the child's abilities, and enhances the child's skills as the child plays games. In today's conditions, since the number of working mothers and hours spent at school by children increased, the educators now must bring children together in this natural way. The inclusion of outdoor activities by teachers according to children's requests and needs, and giving the children opportunities in nature contribute to both children's completion of development, and children to raise as individuals who love and protect nature. This study, it was aimed to investigate whether the activities done in a schoolyard which is intriguing and compelling and has stimulants to support the children's development in the best way have a significant effect on children's social skills and problem behavior.

The study group of the research consists of 19 girls and 21 boys, 40 children in total who attend two kindergartens and two nurseries associated with the Ministry of Family Social Policies in Ankara Province Center. 20 children, 10 girls and 10 boys from one kindergarten and one nursery were assigned to the experiment group, while 20 children, 9 girls and 11 boys from the other kindergarten and nursery were assigned to the control group. A quasi-experimental design with a pretest-posttest control group was used in the research. While the experiment group practiced all of their activities in the garden for three months, the control group continued their education inside of the school. In the data collection, Kindergarten and Nursery Behavior Scale was used as a pre-test and post-test. In the evaluation of data, Whitney U Test, Wilcoxon Signed Ranks Test, Spearman-Brown Correlation Coefficient was benefited from.

It was identified at the beginning of the study that the control and experiment groups showed similar characteristics in terms of Problem Based Learning (PBL) and Social-Emotional Learning (SEL) subdimension scores. As children in the control group were educated inside the school building, the experiment group had their activities run in the garden all day long, for three months. When the pretestposttest results of the experiment and control groups were compared, it was identified that PBL scores of the children who were educated only inside of a classroom environment and didn't use the schoolyard are higher than the PBL scores of the children who were educated in the schoolyard, while the first group's SEL scores were lower. The experiment group continued their education in the class environment for one month after being educated in the schoolyard all day long for three months. Later, the retention test was applied to the experiment group. As a result of these tests, it was found that the experiment group's PBL scores increased and their SEL scores decreased. In the study, it was identified that in the garden application of preschool activities has significant effects on reducing the children's problem behavior and increasing their social skills, but after three months spent in the garden, with the beginning of indoor education again there was the beginning of a decline in the positive outcomes obtained in the children. As a result, the observation of a decrease in the problem behavior of children in the experiment group, and a significant increase in their social skills from before to after the experiment showed that the time spent in the outdoors has a tremendous role in supporting the children's development. Another result of the study is that there is a significant relationship between the social skills of the children and their problem behaviors. It was identified that as the children's social skills increase, their problem behavior decreases.

In this study, the control and experiment group pretest-posttest comparative results showed that both internal and external problem behavior scores of children who were educated only inside a classroom environment and didn't use the schoolyard are higher compared to children who were educated in the schoolyard, while their scores are lower. As a result of the retention test that was applied to the experiment group which continued their education in a classroom environment for one month after their activities were run in the garden all day long for three months, it was observed that their scores increased and their scores decreased. In the study, it was identified that the garden application of preschool activities has significant effects on reducing the children's problem behavior and increasing their social skills. These findings show that a suitable environment has a crucial role in supporting the child's development.

It is possible to find information supporting the obtained results of the study in the literature. For example, Yavuzer (2005) drew attention to the point that children's mental, physical and emotional needs are best satisfied with outdoor games. Outdoors is an important component of supporting children's development and achieving the goals of educational programs (Berk, \& Winsler, 1995). When viewed 
from his perspective, the necessity of the outdoors in educational activities applied to support children's development is understood. Another result obtained from this study is that, as children's social skills increase, their problem behaviors decrease. When the findings are taken into consideration, it can be concluded that garden activities organized with children's high benefits and developmental features taken into consideration have a reducing effect on children's problem behavior by increasing their social skills.

Another result attained from the study is that the social skill levels of the children who were educated in the schoolyard, which is outdoors, increase more compared to the children who were educated inside the classroom environment, which is indoors. This result attained from the study shows that, as pointed out by Rogers and Ross, outdoors is more effective than indoors in the gaining of social skills. In other words, the social independence, social cooperation, and social interaction skills of children in the experimental group improved significantly after garden activities. According to this, it can be said that garden activities are effective in getting children to gain these skills. In their study, Arabacı and Çıtak (2017) remarked that every child aged 3-6 showed great interest in outdoor activities. They also discovered that thanks to their interest in them, children's cognitive, physical, and emotional, even self-care skills were supported with the creative games they played outdoors.

Maria Montessori, who developed her educational approach, also stated that if schools were built in natural environments filled with gardens, fields, poultry and farm animals, rivers, and plants, it would contribute to children to observe the lives of living creatures around them to educate themselves, and become visionary individuals (Cited in: Başal, 2005). Especially children who spend time in natural areas during the 0-6 age period can continue these habits during their adolescence and adulthood with pleasure. Being away from nature during childhood not only negatively affects physical and mental health, but also negatively affects the individual's awareness of understanding and saving nature. If creating healthy individuals and a healthy society is wanted, it is crucial for especially children that are between the ages of 0-6 to be provided to spend time in natural environments (White, 2004). In this study, children in the experimental group made different activities other than the ones made in the company of a teacher. Garden gave children the opportunity of natural observation that requires the individual or peer interactions. Sand, soil, water, plants, or stones in the garden became game materials for children as they set up quite creative games. During the time they spent outdoors, children benefited from the opportunities given by the natural environment. Structured activities were also applied in the garden. Especially, their impressions of animals and plants gave children joyful experiences. Finally, children with social skills can express themselves better and understand others better; they develop positive relationships with their peers and adults. This way, as their conformable behavior increases, their problem behavior can decrease. 